\section{NUMERICAL STUDY OF REINFORCED CONCRETE CORBELS WITH DIFFERENT LAYUP SCHEMES OF CFRP LAMINATES}

\author{
Omid Shabazi Ghozania, Mostafa Moghadasia*, Soheil \\ Taeepoorb
}

aDepartment of Civil Engineering, Faculty of Engineering, Bu-Ali Sina University, Hamedan, Iran

bDepartment of Civil Engineering, Faculty of Engineering, Islamic Azad University, South Tehran, Tehran, Iran
Article history

Received

14 May 2021

Received in revised form

21 September 2021

Accepted

7 November 2021

Published Online

20 December 2021

*Corresponding author m.moghadasi@basu.ac.ir

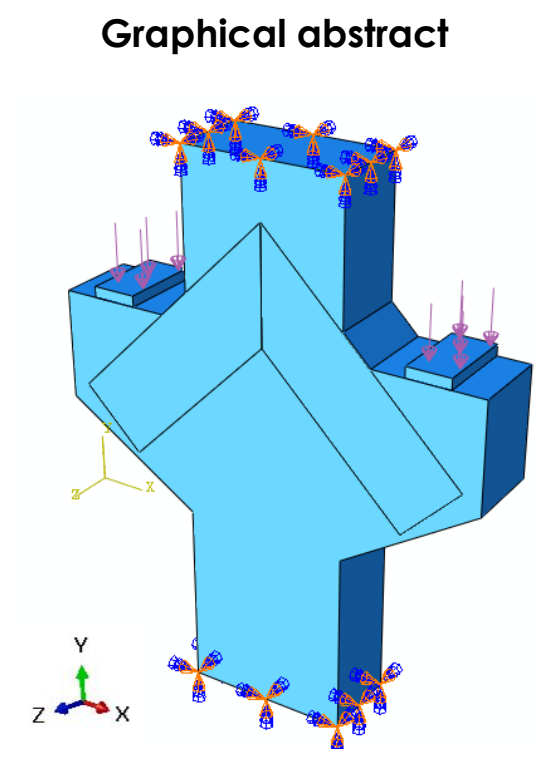

\begin{abstract}
Reinforced concrete short corbels are widely used in engineering structures, such as bridges and precast structures. Therefore, the present comparative study was conducted on the structural behavior of the reinforced concrete corbels strengthened with carbon fiber-reinforced polymer (CFRP) laminates. For this purpose, numerical analysis was done using the finite element method. Therefore, nine models consisting of eight corbels strengthened with different CFRP arrangements in addition to an unstrengthened model were studied. The maximum load capacity, stiffness, ductility, and amount of absorbed energy were compared. In one of the above structure models, an innovative hunch was added at the top side of the corbel to column connection to investigate the differences with ordinary types of connections. Results revealed that the model used three bonded CFRP laminates all around the column and outside edges showed an $81 \%$ increase in loading capacity. Moreover, the corbel equipped with hunches had an $8 \%$ increase in stiffness compared to an ordinary corbel.
\end{abstract}

Keywords: Reinforced concrete corbel, Finite element analysis, CFRP laminate, Bearing capacity, Structural behavior

(C) 2022 Penerbit UTM Press. All rights reserved

\subsection{INTRODUCTION}

Retrofitting the existing structures is extremely important and they can be preserved and functionally improved at minimum cost by employing new methods. Existing structures can be strengthened by applying additional reinforcing elements, such as FRP sheets [1]. In addition, the longevity of a concrete structure is almost estimated between 50 - 100 years. Consequently, after this period, the safety standards of concrete structures will not be satisfied and excessive cracks will appear gradually [2].

Reinforced concrete short corbels are one of the most important structures especially used for precast and pre-stressed concrete beams. They are mostly used to transfer forces from beams to bearing members including columns and walls in precast or reinforced concrete (RC) structures (See Figure 1). These members are formed monolithically with the columns and walls $[3,4]$. 


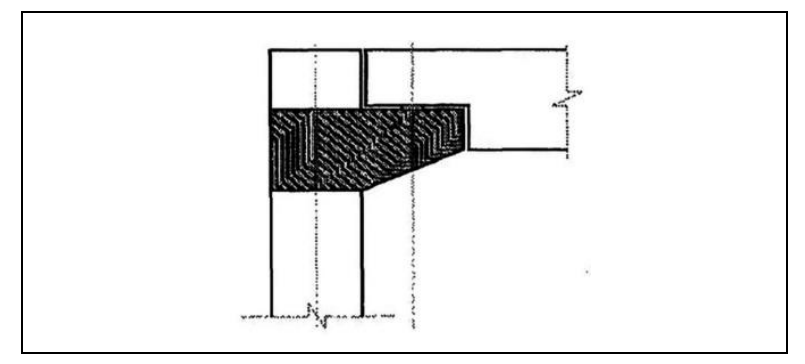

Figure 1 Concrete corbel [3]

The term corbel is generally limited to cantilevers and they generally have a ratio of shear span to effective depth less than one $(\alpha / d<1)$ [5]. Shear behavior of the corbels is influenced by a/d ratio and it has a correlation with deflection of the corbels as well as an inverse relationship with shear capacity [6]. Generally, experimental results are used as the basis for designing corbels. Different types of corbel failures have been indicated in previous experimental investigations, the most outstanding of which are:

1. Yielding to tension tie

2. Failure of end anchorages of tension tie, either under load point or in column

3. Failure of compression strut by crushing or shearing

4. Local zone failure under bearing plate

5. Shear-friction failure at corbel beam to column connection [7]

In reinforced concrete corbels, the presence of high value of shear forces is a leading cause of reduction in their flexural capacity. Hence, there is an urgent need for retrofitting of these structures. The composite usage in the industry was developed during World War II. The preliminary fiber-reinforced polymer (FRP) materials and glass fibers embedded in polymeric resins were made available during this period $[8,9]$. Composite fibers were introduced almost 35 years ago in the field of civil engineering and they were a revolutionary idea for retrofitting and repairing of RC structures [10]. Carbon fiber materials have special characteristics making them beneficial in some aspects. Their low weight and high flexibility as well as their easy implementation and physicochemical properties have made them useful to be applied in retrofitting industry of concrete structures [2]. These fibers need to be aligned with the load in order to be used and transfer the loads into the fibers. Furthermore, fiber's longitudinal axes should be parallel to the loading direction to achieve the best material performance. [11]. Loss of rigidity and low resistance leading to cracking are compensated using carbon fiber materials in concrete short corbels because of strengthening and improving performance and durability of structures [2].

Bonding technique is one of the most popular approaches to increase bearing capacity of concrete corbels when CFRP is bonded on the corbel. Tensile and shear zones appear when the corbel is subjected to bending test (See Figure 2(a)). For strengthening of these weak points, CFRP laminates are bonded in tensile zone as shown in Figure 2(b).

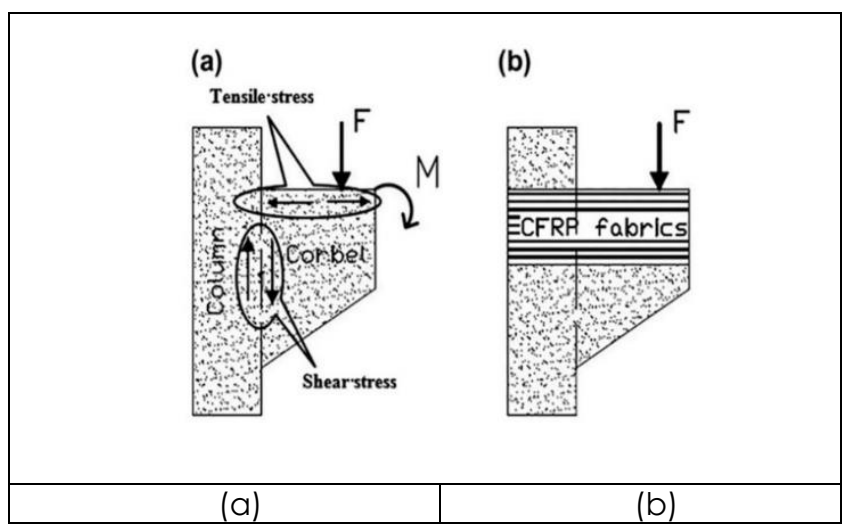

Figure 2 (a) Tensile and shear zones in a typical corbel (b) CFRP laminates bonded in tensile zone [23]

In 1976, Mattock et al., in an experimental study on behavior of the RC corbels subjected to vertical and horizontal loads tested 28 corbels with and without horizontal stirrup reinforcement and with different variables like the shear span to effective depth ratio, the ratio of the vertical load to the horizontal load and the type of aggregate. They developed criteria for the ultimate shear stress in design of lightweight concrete corbels using either shear-friction or modified shearfriction equations [7]. Afterwards in 1997, Norris et al., investigated behavior of 19 damaged or understrength concrete beams retrofitted with CFRP sheets which were epoxy bonded with different orientations (with respect to the axes of the beam) to the tension face and web of concrete beams experimentally and analytically. A remarkable increase was observed in stiffness and strength in retrofitted beams and a fragile failure occurred due to concrete rupture as a result of stress concentration near ends of the CFRPs. Moreover, different orientations of fibers used in beams provided different behaviors under the loads [12].

Furthermore, Campione et al. in 2005 compared the effects of traditional steel reinforcements composed of longitudinal steel bars and transverse stirrups used in concrete corbels with those produced by the use of FRC or due to external wrapping with FRPs in these structures. Corbels were made from medium strength concrete and a $10 \%$ of filer reactive powder (pozzolanic powder) was added to the fresh concrete to increase the workability. Also gravel size effects were considered and the effect of using $10 \mathrm{~mm}$ gravel in $160 \mathrm{~mm}$ corbel compared with typical $20 \mathrm{~mm}$ maximum size. They observed more ductility in the case of using FRC in comparison with traditionally steel reinforcement corbels [13]. In the same year, Elgwady et al. studied six models of the strengthened corbels using CFRP with different configurations as an external strengthening method to understand the effect of CFRPs on bearing capacity of corbels. It is used a towcomponent epoxy to bond CFRP laminates to the 
corbels with different configuration in this study. A 5000- kN machine was used to test the specimens and applied load started at zero in equal increment of 20 $\mathrm{Kn}$ until the observation of the first crack. The results showed that short cantilevers, in which CFRP laminates were used, had an increase in ultimate load in all specimens from 8 to $70 \%$ compared to the control model. Also, they recommended not using two or more wythes of CFRP in some models. Since, high thickness of adhesive in local areas reduces efficiency of the upper layers of CFRPs consequently [3]. Moreover, Ahmad et al. in 2010 tested nine concrete corbels two of which had no CFRP sheets and seven of which were extremely bonded with CFRP sheets in different arrangements. They showed that corbels strengthened with CFRPs had higher shear stress and different CFRP configurations and geometries differently influenced behavior of the loaded corbels. They stated that shear-critical area of some corbels was wrapped in CFRP laminates and the highest strength value was recorded for these specimens [14].

The following year, Syroka et al. studied the behavior of short RC corbels with and without shear reinforcement by quasi-static finite element (FE) simulations. Specimens were modeled with three types of behavior including isotropic elasto-plastic, isotropic damage, and anisotropic smeared crack approach. In this study, a characteristic length of micro-structure through a non-local theory was introduced to ensure the mesh-independent numerical results and describe strain localization. In addition, an associated elastoplastic constitutive model with isotropic hardening was assumed to simulate reinforcement's behavior. They found that tensile fracture energy had almost no effect on the ultimate vertical force but decreasing compressive fracture energy had a reducing effect on the force mentioned above. Furthermore, vertical failure force was increased by $50 \%$ and ductility of RC corbels was improved by the presence of horizontal stirrups. Besides, the elasto-plastic model had the most satisfactory accommodation with corresponding simulated geometry of the localized zones [15]. Afterwards, Rezaei et al. in 2013 studied about normalstrength concrete corbels with $30 \mathrm{FE}$ models, which were different in terms of various parameters, such as ratios of primary and secondary reinforcement and type of the applied loading (vertical or horizontal). They indicated that increasing percentage of primary reinforcement steel can improve the ultimate load of a corbel. Also, load-carrying capacity of a corbel can be increased by adding secondary reinforcement up to $0.3 \%$ [16]. In 2015, Ivanova and Assih investigated behavior of RC short corbels retrofitted by bonding composite carbon fiber fabrics. The effect of some parameters like the influence of strengthening type and using different types of fiber fabrics on the mechanical behavior of these structures are investigated. The results revealed that the structures bonded by carbon fiber fabrics had an increase in failure tensile strength more than 1.82 and also containment effects by wrapping provided a better behavior in corbels than those structures, in which the laminates were glued on front breaking loads. Moreover, it was shown that the stresses in a RC structure can be distributed better by bonding composite carbon fibers [2]. Again, in 2015, Assih et al. investigated strengthening of concrete short corbels by gluing carbon fiber fabrics experimentally and theoretically. In this study, five corbels were tested under three points bending up to failure. Also, they repaired the damaged structures with carbon fiber fabrics and tested them again until their failure. They found that application of composite fiber fabrics using bonding technique is an effective and appropriate method for strengthening concrete structures [17]. In addition, Shadhan and Mohammad Kadhim in the same year tested 16 RC corbels including 14 corbels rehabilitated or strengthened by CFRP laminates in different plies. They considered various parameters in the test program, such as CFRP pattern scheme, bonded type, and damaged ratio. At the end, a remarkable increase in ultimate capacity was observed ranging from 17 to $71 \%$ in the strengthened specimens and from 13 to $65 \%$ in the rehabilitated specimens [18]. In 2017, Neupane et al. tried to numerically and experimentally study a retrofitting solution through the external CFRP wrapping method on the corbels with inappropriate position of bearing pad, which may lead to premature failure. They used different parameters and variables in this study, such as the strength of concrete, shear span, bearing pad location, reinforcement type (CFRP of RC jacketing). It was found that wrong place is at the edge of RC corbel. In addition, CFRP full-wrapped model had more capacity in comparison with other models [19]. Next year, Khosaravikia et al. compared the corbels designed based on the strut and tie model (STM) and results obtained from experimental and non-linear FE analyses. They concluded that it is more conservative to use STM provisions of American association of state highways and transportation officials(AASHTO) load and resistance factor design(LRFD) for designing corbels than experimental and numerical analyses [20].

In 2020, Campione and Cannella investigated an analytical model using strut and tie mechanism in order to evaluate bearing capacity and load deflection response in $\mathrm{RC}$ corbels equipped with secondary steel bars and FRP sheets. They tried to develop manual calculation expressions to predict load carrying capacity of the above-mentioned corbels, which was unique in comparison with other existing models [21]. Afterwards in the same year, AbuObaida et al. modeled two sets of double-sided concrete corbels numerically, which were reinforced with glass fiber-reinforced polymer (GFRP) bars and compared them with previous experimental tests in order to simulate non-linear behavior of RC corbels. In the one set, they adopted a perfect bond assumption between GFRP bars and concrete and in the other set, the researchers adopted a bond stress-slip law at the GFRP concrete interface. It is observed that the models with higher concrete strength were more 
sensitive to the corbel's mechanical ratio and reduction in the ultimate load was more dominant due to increasing $\mathrm{a} / \mathrm{d}$ ratio in these models. Also, application of an interfacial bond stress-slip law at GFRP-concrete interface had no effect on the ultimate load of the corbels in comparison with perfect bond assumption except for four models out 12 models, in which the ultimate load was insignificantly reduced [22]. Ivanova et al. in 2020 did an experimental study to investigate the mechanical behavior of RC corbels strengthened with different CFRP schemes. Using the extensometer technique, they used three-point monotonous flexural loading until the failure to test the specimens and study the local deformations on different points in the constituent materials. It is indicated that the load carrying capacity improved by $80 \%$ in CFRP strengthened specimens compared to the control model (Unstrengthened model). In addition, specimens strengthened by the wrapping method show a better mechanical strength among the specimens [23].

There are some gaps in the literature on RC corbels strengthened with CFRP sheets. Although the term of efficiency as a ratio of the amount of increased strength capacity $(\mathrm{kN})$ to the amount of CFRP's area $\left(\mathrm{cm}^{2}\right)$ could be a significant issue due to the high price of CFRP sheets, it has not been considered in none of the previous studies. Accordingly, in this study, mechanical properties of a corbel strengthened with a wide range of different CFRP layup schemes are analyzed and compared. In addition, herein, the possible effects of an innovative concrete hunch added at top side of the corbel to column connection on mechanical properties of the corbel are investigated.

\subsection{METHODOLOGY}

\subsection{Introduction of Models and Analyses}

In this study, specimens were analyzed statistically using finite element method (FEM). All dimensions of specimens were modeled based on an experimental test done by Ivanova et al. [24] to achieve an accurate verification (See Figure 3). Also, for numerical and analytical modeling, ABAQUS/CAE 4.14-2 software was used and it was tried to have the minimum geometrical changes in all models. The concrete corbels and their reinforcing details modeled in ABAQUS/CAE software are shown in Figure 4.

The static load was applied in a monotonic manner until occurrence of the failure in each model. In this study, all the models were modeled with 3D elements and four-sided meshing with dimensions of $30 * 30 \mathrm{~mm}$ (Figure 5).

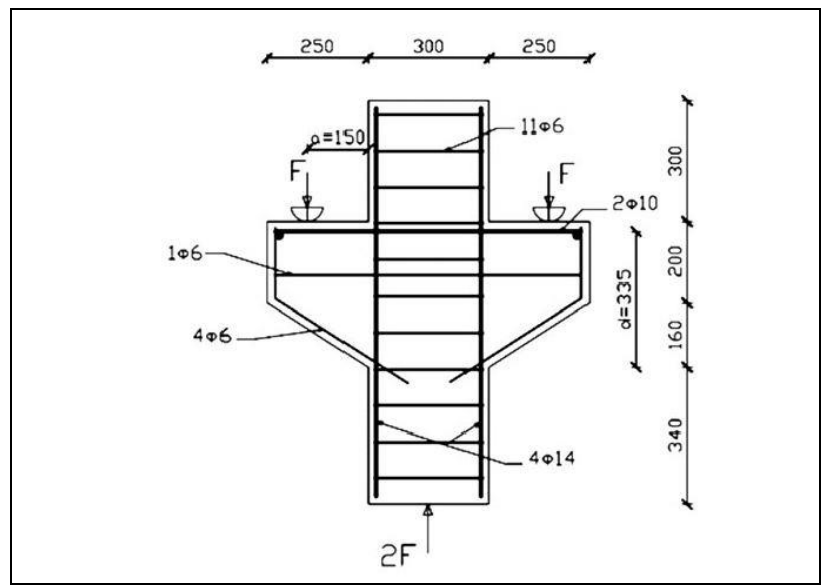

Figure 3 Corbel geometry and reinforcing details (23)

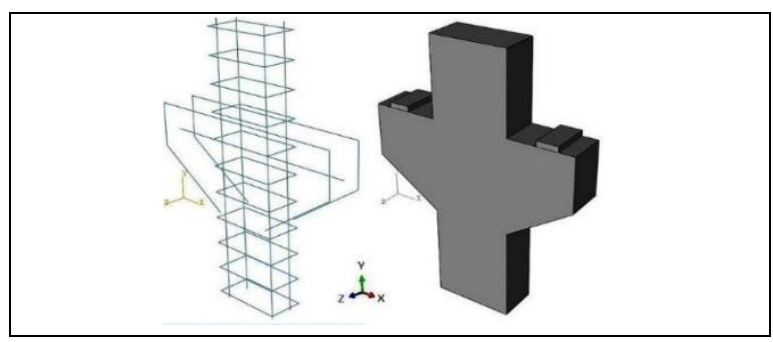

Figure 4 Graphical model of corbel geometry and reinforcing details in $A B A Q U S$ software

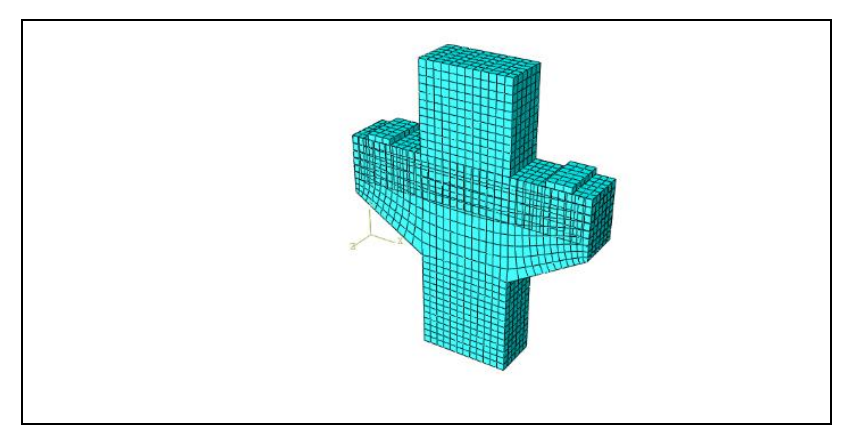

Figure 5 Graphical model of meshing elements details in ABAQUS software

\subsection{Material Properties}

\subsubsection{Concrete}

Since, in the current study, an experimental model proposed by Ivanova et al. [24] was utilized so herein, concrete and steel characteristics were similar to the above experimental program. Therefore, Hognestad [25] strain-stress model was applied for concrete as it has been used by many researchers in the previous similar works. Concrete damage plasticity (CDP) was chosen as a pre-defined concrete damage simulation model proposed by ABAQUS/CAE software. Concrete compressive strength was equal to $32.2 \mathrm{MPa}$, modulus of elasticity, and Poisson's ratio were equal to $30 \mathrm{GPa}$ and 0.25 , respectively. 
The C3D8R was considered as the element used for concrete modeling in software. This element is a threedimensional, linear hexahedral brick. Furthermore, it has eight nodes with reduced integration points.

\subsubsection{Steel}

In this research, steel behavior was assumed to be elastoplastic with bilinear stress-strain diagram. Furthermore, mechanical characteristics of steel bars are shown in Table 1.

T3D2 is a linear two-node truss element with three degrees of freedom at each node in the global coordinate. The rebars consist of longitudinal steel and stirrups modeled as T3D2 elements. In addition, in this study, a bonding was assumed between steel and concrete as embedded using pre-defined interaction provided by ABAQUS/CAE software.

Table 1 Mechanical properties of steel bars [24]

\begin{tabular}{c|c|c|c|c|c|c}
\hline $\begin{array}{c}\mathbf{E}_{\mathbf{s}} \\
(\mathbf{G P a})\end{array}$ & $\boldsymbol{\varepsilon}_{\mathbf{u}}$ & $\begin{array}{c}\mathbf{f}_{\mathbf{u}} \\
(\mathbf{M P a})\end{array}$ & $\boldsymbol{\varepsilon}_{\mathbf{y}}$ & $\begin{array}{c}\mathbf{f}_{\mathbf{y}} \\
(\mathbf{M P a})\end{array}$ & $\boldsymbol{v}$ & $\begin{array}{c}\mathbf{\rho} \\
\left.\mathbf{k g} / \mathbf{m}^{3}\right)\end{array}$ \\
\hline 200 & 0.1104 & 610 & 0.0025 & 508 & 0.3 & 7850 \\
\hline
\end{tabular}

Note: $\mathrm{E}_{\mathrm{s}}$ : Modulus of elasticity, $\boldsymbol{\varepsilon}_{\mathbf{u}}$ : Ultimate strain, $\mathrm{f}_{\mathrm{u}}$ : Ultimate Stress, $\varepsilon_{\mathbf{y}}$ : Yield strain, $\mathrm{f}_{\mathrm{y}}$ : Yield stress, $v$ : Poisons ratio, $\rho$ :Density

\subsubsection{CFRP Laminates}

Since, the CFRP laminates utilized in this paper consisted of unidirectional fibers; it was far from reality to consider them as isotropic materials. In other words, mechanical properties of these materials were not the same in different directions. Herein, the characteristics of composite polymer laminate strengthened with carbon fibers were defined in the software with regard to the characteristics extracted from experimental specimens. Thickness of all the CFRP laminates was equal to $1 \mathrm{~mm}$ and other specifications are available in Table 2.

A four-node quadrilateral shell element with reduced integration called as $S 4 R$ was used for modeling the CFRP laminate in the software.

\subsection{Loading and Boundary Conditions}

\subsubsection{Loading}

In this study, vertical load for concrete corbels was considered as an external load applied on a steel plate inserted on two sides of the structures (See Figure 6).

\subsubsection{Boundary Condition}

The specifications of corbel supports were modeled as considered by Ivanova et al. [24]. These supports are shown in Figure 6.

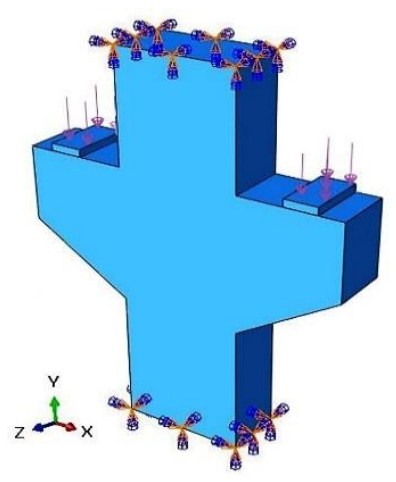

Figure 6 Applying external loads on bearing plates and boundary conditions

\subsection{Different CFRP Layup Schemes}

In this paper, various corbels with different CFRP arrangements were strengthened and investigated. For this purpose, eight specimens with different CFRP adjustments were analyzed and then, various results were extracted and compared with control mode. In Table 3, terminology and characteristics of the models are expressed. In addition to applying various CFRP arrangements in concrete corbels, one model (Cl2) was equipped with a hunch placed at top sides of corbel to column connection. Geometry of hunches included an equilateral right triangle with two legs of $50 \mathrm{~mm}$. Therefore, all the corbel specimens are shown in Figure 7.

Table 2 Mechanical characteristic of CFRP laminates, based on Ivanova et al. experimental investigation [24]

\begin{tabular}{|c|c|c|c|c|c|c|c|}
\hline $\begin{array}{l}* G 23 \\
(\mathrm{MPa})\end{array}$ & $\begin{array}{c}\text { G13 } \\
\text { (MPa) }\end{array}$ & $\begin{array}{c}\text { G12 } \\
\text { (MPa) }\end{array}$ & Nu12 & $\begin{array}{c}\text { E2 } \\
\text { (MPa) }\end{array}$ & $\begin{array}{c}E 1 \\
(\mathrm{MPa})\end{array}$ & $* * \varepsilon_{y}$ & $\begin{array}{c}\boldsymbol{\rho} \\
\boldsymbol{k g} / \boldsymbol{m}^{3}\end{array}$ \\
\hline 4535 & 4535 & 4535 & 0.45 & 6650 & 86000 & $\begin{array}{c}0.00 \\
8\end{array}$ & 1600 \\
\hline $\begin{array}{l}\text { Note: *G } \\
\text { strain }\end{array}$ & & & & & & & ${ }^{*} \varepsilon_{y}:$ Yield \\
\hline
\end{tabular}


Table 3 Terminology of the corbel specimens

\begin{tabular}{|c|c|c|c|c|c|}
\hline \multirow[b]{2}{*}{ No. } & \multirow[b]{2}{*}{ Terminology } & \multicolumn{3}{|c|}{ CFRP Laminate specifications } & \multirow[b]{2}{*}{ Type of arrangement } \\
\hline & & No. of strips * & $\begin{array}{l}\text { No. of } \\
\text { layers }\end{array}$ & $\begin{array}{l}\text { Width } \\
(\mathrm{mm})\end{array}$ & \\
\hline 1 & $\mathrm{CO}$ & - & - & - & Unstrengthened model. \\
\hline 2 & $\mathrm{CH} 1$ & 1 (Horizontal) & 3 & 150 & $\begin{array}{l}\text { One horizontal CFRP strip fully surrounded at two face. Each strip } \\
\text { consists of one layer. }\end{array}$ \\
\hline 3 & $\mathrm{CH} 2$ & 3 (Horizontal) & 1 & 50 & $\begin{array}{l}\text { Three horizontal CFRP strips at two faces. Each strip consists of one } \\
\text { layer. }\end{array}$ \\
\hline 4 & $\mathrm{CH} 3$ & 3 (Horizontal) & $\begin{array}{l}\text { 3: Top } \\
\text { 2: Middle } \\
\text { 1: Bottom }\end{array}$ & 50 & $\begin{array}{l}\text { Three horizontal CFRP strips. Upper strip consists of three layer, middle } \\
\text { strip consists of two layer and the bottom consists of one layer. }\end{array}$ \\
\hline 5 & $\mathrm{Cll}$ & 2 (Inclined) & 1 & 150 & $\begin{array}{l}\text { Two symmetric inclined CFRP strips with the } 45 \text { degree at two faces. } \\
\text { Each strip consists of one layer. }\end{array}$ \\
\hline 6 & $\mathrm{Cl} 2$ & 2 (Inclined) & 1 & 150 & $\begin{array}{l}\text { Two symmetric inclined CFRP strips with the } 45 \text { degree at two faces. } \\
\text { Each strip consists of one layer. A concrete hunch with a leg length of } \\
50 \mathrm{~mm} \text { is placed at intersection of middle column and outside edges }\end{array}$ \\
\hline 7 & $\mathrm{ClH}$ & $\begin{array}{l}3 \text { (2 inclined \& } 1 \\
\text { Horizontal) }\end{array}$ & 1 & 150 & $\begin{array}{l}\text { One horizontal and two inclined CFRP strips with the } 45 \text { degree at two } \\
\text { faces. Each strip consists of one layer. }\end{array}$ \\
\hline 8 & $\mathrm{CV}$ & 4 (Vertical) & 1 & 100 & Four vertical CFRP strips at two faces. Each strip consists of one layer. \\
\hline 9 & $\mathrm{CHV}$ & $\begin{array}{l}5 \text { (1 Horizontal \& } 4 \\
\text { Vertical) }\end{array}$ & 1 & 100 & $\begin{array}{l}\text { Four vertical and one horizontal CFRP strips at two faces. Each strip } \\
\text { consists of one layer. }\end{array}$ \\
\hline
\end{tabular}

Note: *Number of strips at each face of the corbels.

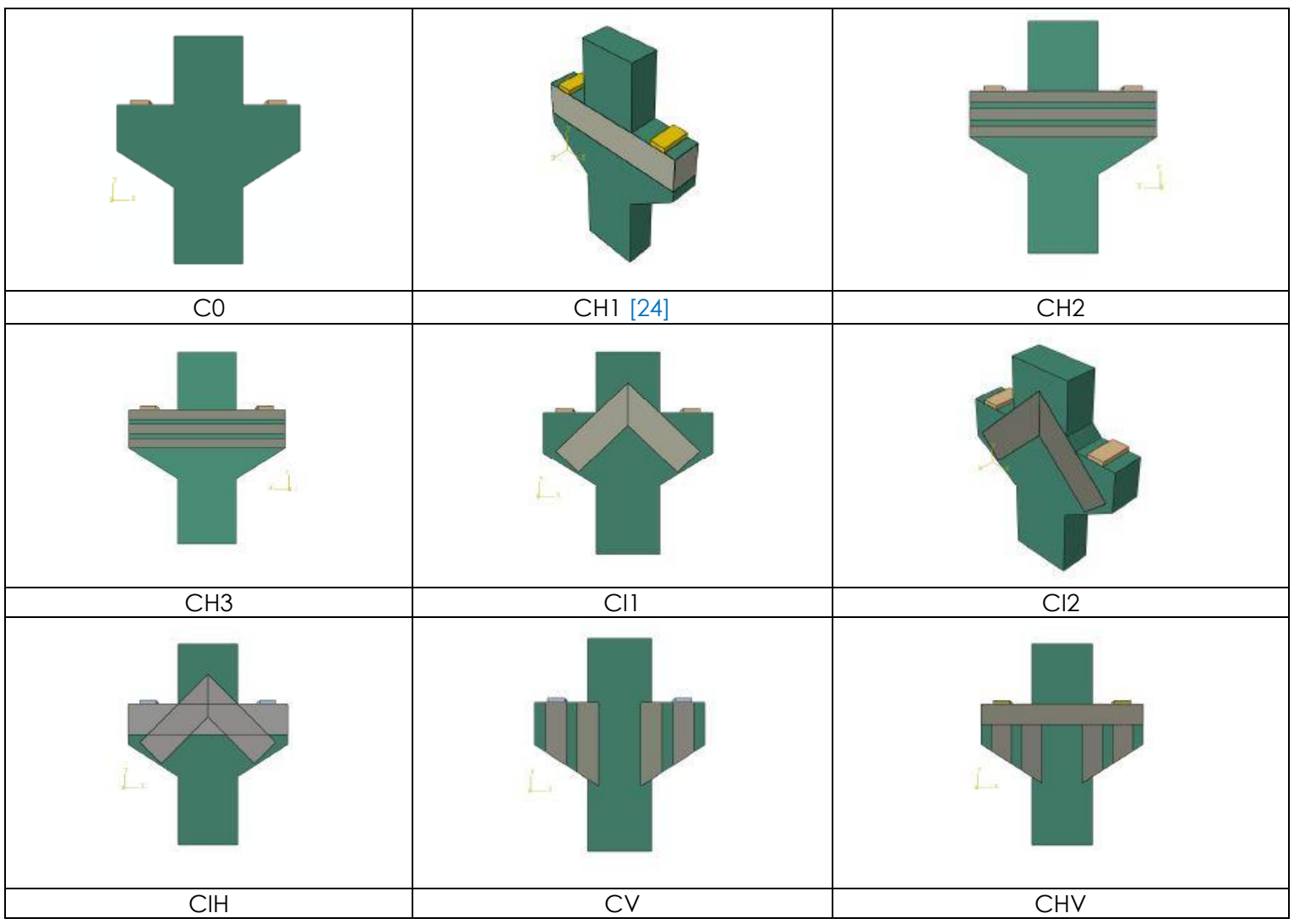

Figure 7 CFRP arrangements in the strengthened models 


\subsection{Verification and Comparison between the FEM Models and Experimental Tests}

$\mathrm{CH} 1$ is the model introduced by Ivanova et al. [24] in their experimental investigation and it is used in this study to be compared with different arrangements of CFRP laminates. In this specimen, three CFRP laminates with a width of $150 \mathrm{~mm}$ were wrapped horizontally on both sides of the corbel. For achieving a precise verification, the load-strain diagram for longitudinal bars and CFRP laminates extracted from the model introduced by Ivanova et al. [24] was compared with $\mathrm{CHI}$ model and results are shown in Figures 8 and 9 , respectively.

Obviously, both diagrams are following the same trend and analysis showed a close proximity between the two sets of results.

As the load was increased and the corbel approached to failure mode, the amount of ultimate load reached to $651.8 \mathrm{kN}$ for CFRP laminates, which was reported by $651 \mathrm{kN}$ in experimental investigation by Ivanova et al. [24].

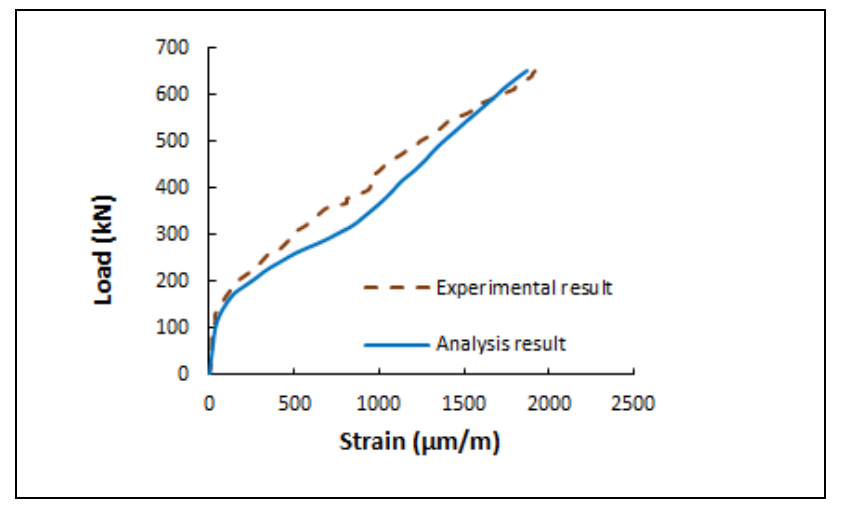

Figure 8 Comparison of load-strain diagrams (experimental study by Ivanova et al., [24] and $\mathrm{CH}$ model for longitudinal bars)

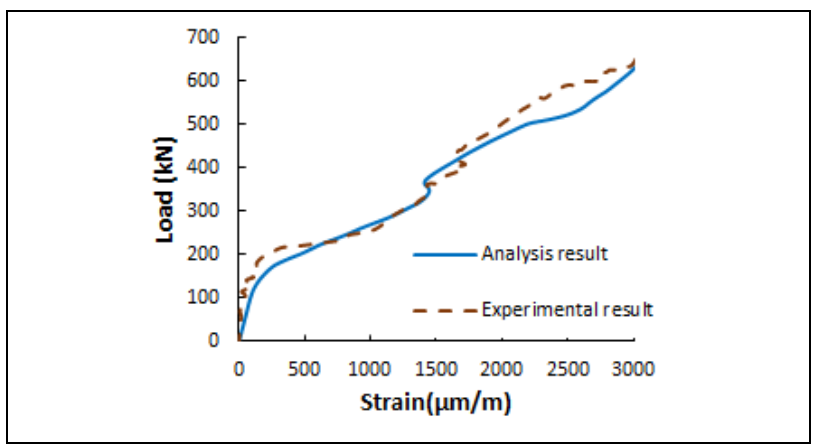

Figure 9 Comparison of load-strain diagrams (experimental study by Ivanova et al., [24] and $\mathrm{CH}$ model for CFRP laminate)

\subsection{RESULTS AND DISCUSSION}

In this section, results of numerical analysis on the reinforced concrete corbel models are presented. Different CFRP layup schemes using horizontal laminates, diagonal laminates with 45-degree angle, vertical laminates, and combinational laminates are investigated. These results are presented in Table 4.

Table 4 The amount of ultimate load, ductility, stiffness and absorbed energy for different CFRP layup schemes

\begin{tabular}{|c|c|c|c|c|}
\hline Model & $\begin{array}{l}\text { Ultimate } \\
\text { load } \\
\text { (kN) }\end{array}$ & $\begin{array}{c}\text { Factor of } \\
\text { Ductility } \\
*\end{array}$ & $\begin{array}{l}\text { Stiffness } \\
(\mathrm{kN} / \mathrm{mm} \\
\end{array}$ & $\begin{array}{l}\text { Absorbed } \\
\text { energy } \\
\text { (kN.mm) }\end{array}$ \\
\hline $\mathrm{CO}$ & 360 & 7.3 & 1867.7 & 132 \\
\hline $\mathrm{CHI}$ & 651.8 & 11.5 & 1930.5 & 366.1 \\
\hline $\mathrm{CH} 2$ & 540 & 10.7 & 1895.8 & 283.4 \\
\hline $\mathrm{CH} 3$ & 621 & 10.8 & 1912.5 & 335.6 \\
\hline $\mathrm{Cll}$ & 495.6 & 10.5 & 1891.8 & 258.9 \\
\hline $\mathrm{Cl} 2$ & 516 & 11.4 & 2121.4 & 281 \\
\hline $\mathrm{ClH}$ & 564 & 10.5 & 1909.9 & 287.6 \\
\hline $\mathrm{CV}$ & 472.8 & 10.5 & 1884.6 & 257.2 \\
\hline $\mathrm{CHV}$ & 542.3 & 11 & 1872.5 & 315.3 \\
\hline
\end{tabular}

\subsection{Force-Displacement Results}

Figure 10 shows incremental force-displacement diagram in all the models. Based on these diagrams, mechanical characteristics of corbel structures including ultimate load, ductility, stiffness, and absorbed energy are discussed in the following sections.

\subsubsection{Ultimate Load strength}

As shown in Table 4, the $\mathrm{CH} 1$ model tolerated the most ultimate load among the other specimens by $651.8 \mathrm{kN}$. In addition, $\mathrm{CH} 3$ had almost similar ultimate load to $\mathrm{CH} 1$ with a variation of $4.7 \%$ by $621 \mathrm{kN}$. Furthermore, the $\mathrm{ClH}$ model was third in terms of ultimate load capacity after these two models by $564 \mathrm{kN}$. The increase in ultimate load capacity of the models compared to $\mathrm{CO}$ varied between $32-81 \%$ for $\mathrm{CV}$ and $\mathrm{CHI}$, respectively.

$\mathrm{CH} 1$ and $\mathrm{CH} 3$ models have the highest ultimate load capacities because of three layers of CFRP sheets located at the tension zone of the corbel. 


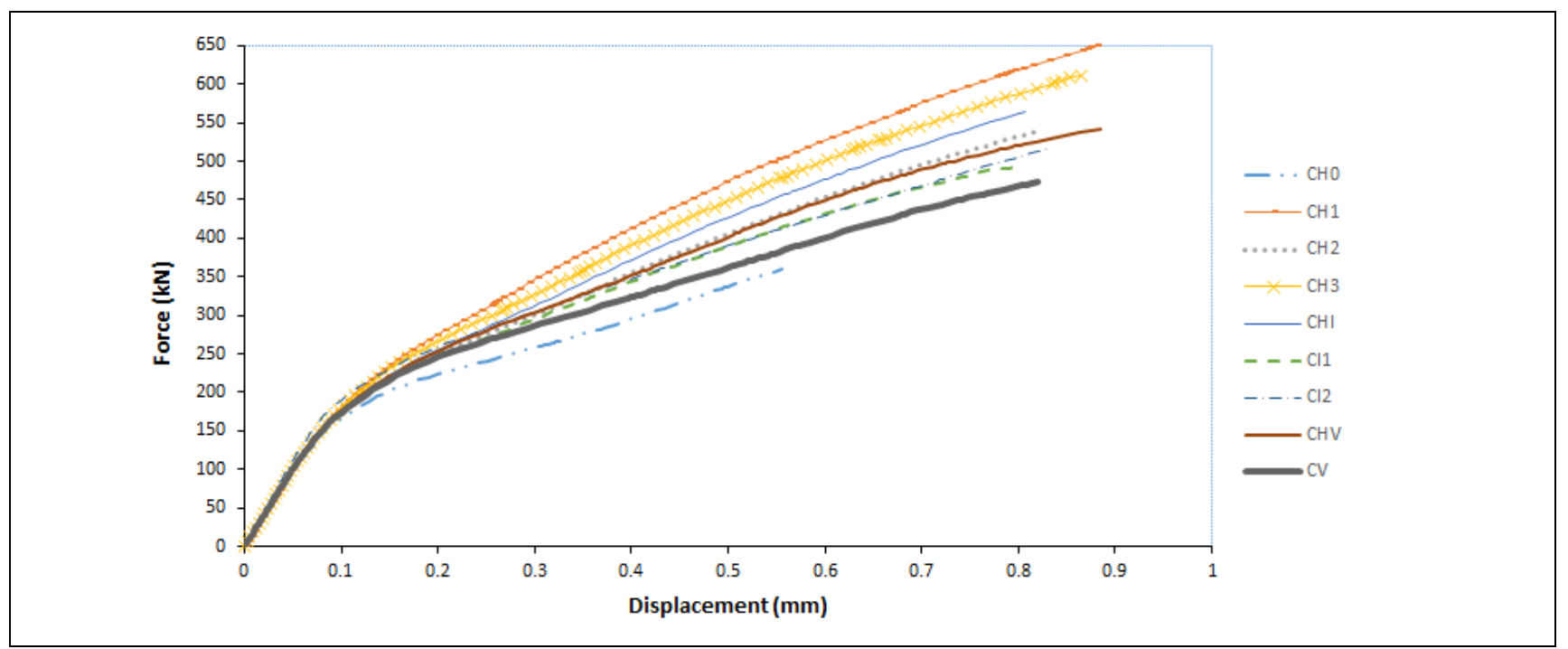

Figure 10 Force-displacement diagrams for all the models

\subsubsection{Ductility}

In this study, ductility is defined as the ratio of ultimate deflection, $\Delta_{u}$, to the deflection at initial yield, $\Delta_{y}$, proposed by Loo and Yao in 1995 [26]. According to this definition, model $\mathrm{CH} 1$ was more ductile than the other models with $57 \%$ increment in comparison with the control model (CO), which is due to the fact that concrete corbel was wrapped with three layers of CFRP laminates, which are more ductile than the concrete itself.

Moreover, the $\mathrm{Cl} 2$ model, equipped with hunches, had the highest ductility and its correspondent model (CI1) had the lowest along with $\mathrm{CV}$ and $\mathrm{ClH}$ models. It shows the effectiveness of added concrete hunches to the corbel. As expected, the control model was the most brittle one among all the specimens.

\subsubsection{Stiffness}

$\mathrm{Cl} 2$ model equipped with hunches in two sides of the corbel to column connection reached the highest stiffness by $2121.4 \mathrm{kN} / \mathrm{mm}$ and it is more than $12 \%$ and $14 \%$ stiffer than the same model without hunch (CI1) and control model (CO), respectively. While, the $\mathrm{CHI}$ model proposed by Ivanova et al. [24] had the highest stiffness after the $\mathrm{Cl} 2$ model with a difference of about $9 \%$ showing that adding a small hunch at the corbel to column connection and using only one inclined CFRP laminate increases stiffness of the model $10 \%$ higher than the model equipped with three horizontal layers without using hunches.

\subsubsection{Absorbed Energy}

In the case of the absorbed energy, the $\mathrm{CH}$ l model had the highest capacity along with the highest ductility among the other specimens. Particularly, energy absorbed by the control structure until the failure was multiplied by 2.8 using three horizontal CFRP layers around the corbel. After that, $\mathrm{CH} 3$ and $\mathrm{CHV}$ models were in the second and third places by land $1.4 \%$ of absorbed energy, respectively, which is a very little difference.

\subsubsection{Modes of Failure}

Table 5 presents failure modes, ultimate loads and their related displacement, load required for occurrence of the first crack and its correspondent displacement, and ratio of the ultimate load of each model to the control model. Dominant mode of failure in majority of the models was CFRP rupture. In the other words, concrete fracture was prevented by wrapping the CFRP laminates in all the specimens. Additionally, load required at the first crack occurrence was increased in the wrapped models and this was more obvious in the model equipped with two small hunches, which had the highest stiffness among the others ( $\mathrm{Cl} 2$ model). Furthermore, the first crack almost occurred in the same amount of displacement in all the models. Failure modes for $\mathrm{CH} 1$ and $\mathrm{Cl} 2$ models as an example of concrete fracture and CFRP rupture are shown in Figures 11 and 12, respectively.

\subsection{Efficiency of Layup Schemes}

For having an accurate judgment, efficiency of each strengthened model was calculated. For this purpose, as mentioned before, a parameter, which is a ratio of the amount of increased strength capacity $(\mathrm{kN})$ to the amount of CFRP's area $\left(\mathrm{cm}^{2}\right)$ utilized in a corbel multiplied by 100 was introduced. This ratio represents that how much resistance can be obtained by adding $1 \mathrm{~cm}^{2}$ to the control model (See Table 6). As depicted in Table 6, the $\mathrm{CH} 1$ model represented by Ivanova et al. [24] had the lowest efficiency by 3.41. On the other 
hand, $\mathrm{CH} 2$ and $\mathrm{Cl} 2$ models had the highest efficiency by 7.5 and 6.42 , respectively.

Ivanova's model $(\mathrm{CH} 1)$ has the highest ultimate load among the models with $651.8 \mathrm{kN}$ (See Table 4) because of three layers of wrapped CFRP around this model. This high amount of CFRP sheets utilized in $\mathrm{CH} I$ has made the efficiency factor of the model extremely low in comparison with other models. The efficiency factor of the $\mathrm{CH} 2$ model is the highest and its ultimate load is just $17 \%$ lower than the $\mathrm{CH} 1$ model with $621 \mathrm{kN}$. In addition, according to Table 6, the increased strength capacity for the $\mathrm{CH} 3$ model is 261 which is just $10.5 \%$ lower than Ivanova's model $(\mathrm{CH})$ but its efficiency factor is about $59.5 \%$ higher than the $\mathrm{CH} 1$ model. In the $\mathrm{CH} 3$ model, it is tried to make the areas with more tension stress more strengthened.

The model equipped with two concrete hunches (Cl2) has the second highest efficiency while it has the highest amount of stiffness and ductility. Furthermore, it could be seen that the addition of a small concrete hunch to the top side of the corbel to column connection creates a tensile brace between the corbel and the column. This bracing behavior has made it $15 \%$ more efficient than its corresponding model without hunch (Cl1).

Table 6 Efficiency of layup schemes

\begin{tabular}{c|c|c|c}
\hline Model & $\begin{array}{c}\text { Strength } \\
\text { capacity } \\
\text { added to C0 } \\
\text { (kN) }\end{array}$ & $\begin{array}{c}\text { CFRP } \\
\text { area(cm }\end{array}$ & $\begin{array}{c}\text { Efficiency } \\
\text { Factor* }\end{array}$ \\
\hline $\mathrm{CH} 1$ & 291.8 & 8550 & 3.41 \\
\hline $\mathrm{CH} 2$ & 180 & 2400 & 7.50 \\
\hline $\mathrm{CH} 3$ & 261 & 4800 & 5.44 \\
\hline $\mathrm{Cl} 1$ & 135.6 & 2430 & 5.58 \\
\hline $\mathrm{Cl} 2$ & 156 & 2430 & 6.42 \\
\hline $\mathrm{ClH}$ & 204 & 4830 & 4.22 \\
\hline $\mathrm{CV}$ & 112.8 & 2500 & 4.51 \\
\hline $\mathrm{CHV}$ & 182.28 & 4100 & 3.41 \\
\hline
\end{tabular}

Table 5 Failure modes with its correspondent loads and displacements

\begin{tabular}{c|c|c|c|c|c|c}
\hline Model & $\begin{array}{c}\boldsymbol{P}_{\boldsymbol{c}}{ }^{*} \\
(\mathbf{k N})\end{array}$ & $\begin{array}{c}\boldsymbol{P}_{\boldsymbol{u}}{ }^{* *} \\
(\mathbf{k N})\end{array}$ & $\begin{array}{c}\Delta_{\boldsymbol{c}} \mathbf{\boldsymbol { }} \\
(\mathbf{m m})\end{array}$ & $\begin{array}{c}\Delta_{\boldsymbol{u}} \mathbf{t T} \\
(\mathbf{m m})\end{array}$ & $\boldsymbol{P}_{\boldsymbol{u}} / \boldsymbol{P}_{\mathbf{0}}^{* * *}$ & Failure mode \\
\hline $\mathrm{C} 0$ & 140.4 & 360 & 0.079 & 0.67 & 1 & Brittle failure-Cracking in tensile area \\
\hline $\mathrm{CH} 1$ & 149.92 & 651.84 & 0.08 & 0.99 & 1.81 & Brittle failure- Cracking in tensile area \\
\hline $\mathrm{CH} 2$ & 145.8 & 540 & 0.08 & 0.99 & 1.5 & CFRP rupture \\
\hline $\mathrm{CH} 3$ & 153 & 621 & 0.08 & 0.99 & 1.72 & Brittle failure- Cracking in tensile area \\
\hline $\mathrm{Cl}$ & 143.72 & 495.6 & 0.08 & 0.99 & 1.37 & CFRP rupture \\
\hline $\mathrm{Cl} 2$ & 154.8 & 516 & 0.081 & 0.99 & 1.43 & CFRP rupture \\
\hline $\mathrm{ClH}$ & 146.64 & 564 & 0.08 & 0.99 & 1.56 & CFRP rupture \\
\hline $\mathrm{CV}$ & 146.57 & 472.8 & 0.08 & 0.99 & 1.36 & CFRP rupture \\
\hline $\mathrm{CHV}$ & 149.04 & 542.28 & 0.08 & 0.99 & 1.5 & CFRP rupture \\
\hline
\end{tabular}

*Load required at the first crack occurrence. ${ }^{* *}$ Ultimate load. ${ }^{* *}$ Ultimate load for the control model

tDisplacement at the first crack occurrence. t† Ultimate displacement.
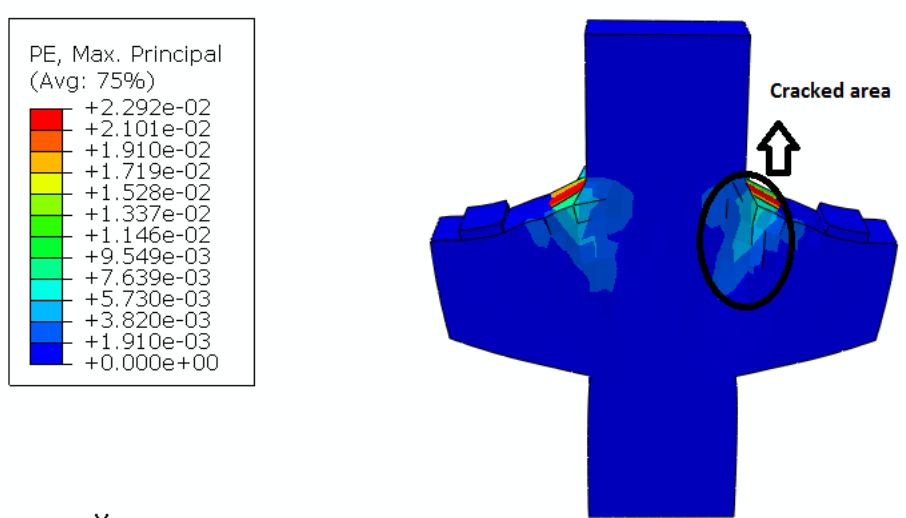

$\underset{\mathrm{C}}{\mathrm{Y}}$

ODB: L6601631858406.554.odb Abaqus/Standard 6.14-2 Thu Dec 28 14:09:13 Iran Standard Time 2017

Step: Step-1

Increment 115: Step Time $=1.000$

Primary Var: PE, Max. Principal

Figure 11 Failure mode of $\mathrm{CH} 1$ model (Cracked area at the corbel to column connection) 


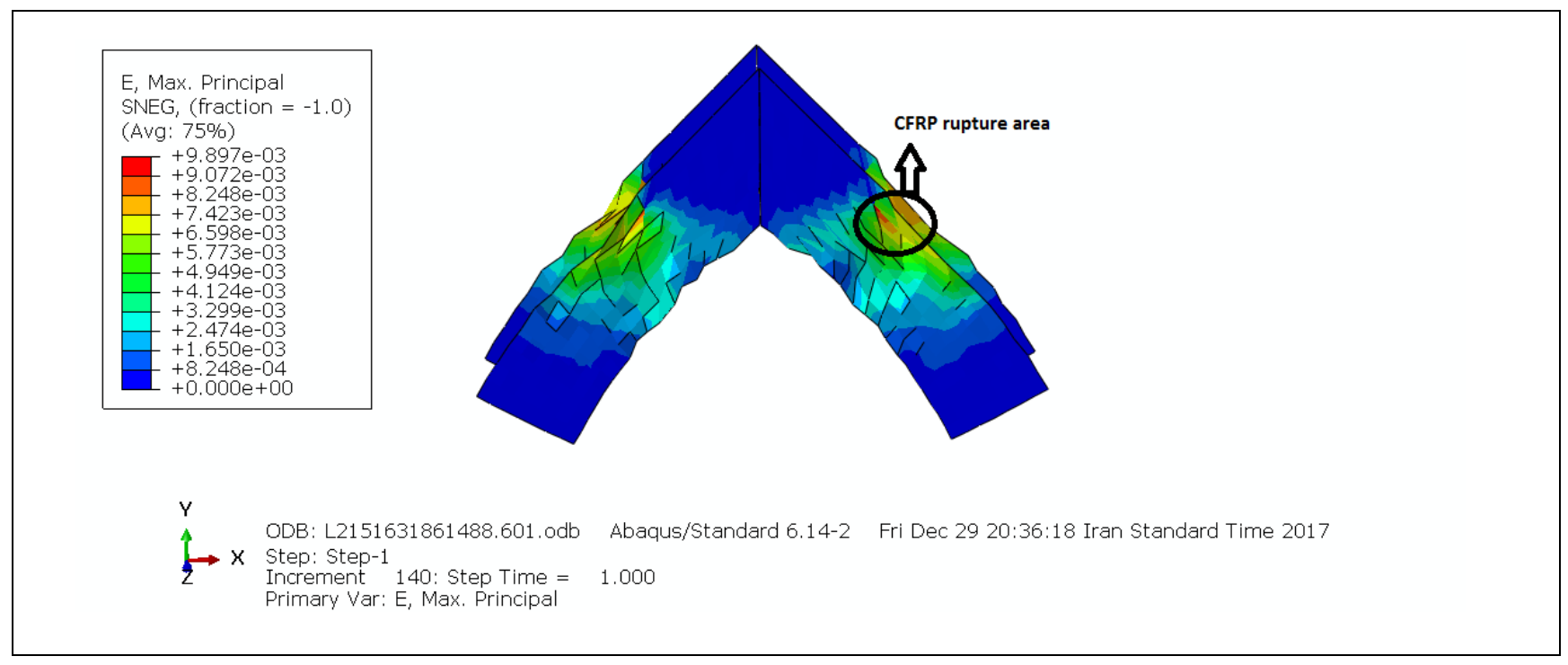

Figure 12 Failure mode of $\mathrm{Cl} 2$ model (Rupture of CFRP sheets)

\subsection{CONCLUSION}

In this study, eight different arrangements of CFRP laminates named $\mathrm{CH} 1, \mathrm{CH} 2, \mathrm{CH} 3, \mathrm{Cl}, \mathrm{Cl} 2, \mathrm{Cl}, \mathrm{CV}$, and $\mathrm{CHV}$ wrapped on the short corbel structure were analyzed numerically by non-linear FE analysis and were compared with an unstrengthened model named as $\mathrm{C} 0$. The following conclusions can be drawn according to findings of the study:

Load carrying capacity was increased in various specimens strengthened with CFRP laminates compared to the unstrengthened model by $81.05,50$, $72.5,37.6,43.3,56.6,31.3$, and $50.6 \%$ for $\mathrm{CH} 1, \mathrm{CH} 2$, $\mathrm{CH} 3, \mathrm{Cl} 1, \mathrm{Cl} 2, \mathrm{ClH}, \mathrm{CV}$, and $\mathrm{CHV}$, respectively.

The model equipped with a small hunch at the corbel to column connection $(\mathrm{Cl} 2)$ had the highest amount of stiffness among the other models. This model had almost $10 \%$ more stiffness than the $\mathrm{CH}$ model, which had the second place in terms of stiffness among the models. In addition, two small hunches in two sides of the corbel to column connections postponed occurrence of the first crack in comparison with the same model without hunches by more than $7 \%$. Also, $\mathrm{Cl} 2$ model showed an $8 \%$ more increment in the amount of stiffness, $15 \%$ more increment in added strength capacity, $8.5 \%$ more ductility and absorbed energy in comparison with the same model with similar layup scheme but without hunch (Cl1).

$\mathrm{CH}$ l model had the highest amount of both absorbed energy and structural ductility by 366.1 $\mathrm{kN} . \mathrm{mm}$ and 11.5, respectively. This model also had the highest increment in load carrying capacity by 651.8 $\mathrm{kN}$. On the other hand, the mentioned model had the most utilized CFRP area, which made it inefficient with the least efficiency level (3. 41) among the other models. On the contrary, $\mathrm{CH} 2$ model had the maximum efficiency level of 7.5 among all the other models. It could be concluded that the $\mathrm{CH} 2$ model was about 2.2 times more efficient than $\mathrm{CH}$ model proposed by Ivanova et al., (2015).

The use of CFRP laminates is a leading cause of increment in load creating the first crack. As an example, this load was increased by 7 and $10 \%$ using horizontal layup scheme technique and diagonal technique, respectively.

Increased strength capacity and ductility factor in the CV model with vertical CFRP sheets is the lowest among the models. Increased strength capacity in this model is $61.3 \%$ lower than this factor in Ivanova's model.

\section{References}

[1] Zilch, K., Niedermeier, R. and Finckh, W. 2014. Strengthening of Concrete Structures with Adhesively Bonded Reinforcement: Design and Dimensioning of CFRP Laminates and Steel Plates. John Wiley \& Sons. DOI: https://doi.org/10.1002/9783433604014.

[2] Ivanova, I. and Assih, J. 2015. Experimental Study of Local Behavior of Strengthened Reinforced Concrete Short Corbel by Bonding Carbon Fiber Fabrics. Int. J. Struct. Civ. Engg. Res. 4(1).

[3] Elgwady, M. A., Rabie, M. and Mostafa, M. T. 2005. Strengthening of Corbels using CFRP an Experimental Program. Cairo University, Giza, Egypt.1-9.

[4] Campione, G., La Mendola, L. and Papia, M. 2005. Flexural Behaviour of Concrete Corbels Containing Steel Fibers or Wrapped with FRP Sheets. Materials and Structures. 38(6): 617-625. DOI: https://doi.org/10.1007/BF02481593.

[5] $\mathrm{ACl}$ Committee 318. 2019. Building Code Requirements for Structural Concrete $(\mathrm{ACl} 318-14)$ and Commentary. Farmington Hills: American Concrete Institute.

[6] Md Zin, N., Al-Fakih, A., Nikbakht, E., Teo, W. and Anwar Gad, M., 2019. Influence of Secondary Reinforcement on Behaviour of Corbels with Various Types of HighPerformance Fiber-Reinforced Cementitious Composites. Materials, 12(24): 4159.

DOI: https://doi.org/10.3390/mal2244159. 
[7] Mattock, A. H., Chen, K. C. and Soongswang, K. 1976. The Behavior of Reinforced Concrete Corbels. PCl Journal, 21 (2): 52-77.

DOI: https://doi.org/10.15554/pcii.0301 1976.52.77.

[8] Bakis, C. E., Bank, L. C., Brown, V., Cosenza, E., Davalos, J. F., Lesko, J. J., Machida, A., Rizkalla, S. H. and Triantafillou, T. C. 2002. Fiber-reinforced Polymer Composites for Construction-State-Of-The-Art Review. Journal of Composites for Construction. 6(2): 73-87.

DOl:https://doi.org/10.1061/(ASCE) 1090-0268(2002)6:2(73).

[9] Bhatt, A. T., Gohil, P. P. and Chaudhary, V. 2018. March. Primary Manufacturing Processes for Fiber Reinforced Composites: History, Development \& Future Research Trends. IOP Conference Series: Materials Science and Engineering. IOP Publishing. 330(1): 012107. DOI: https://doi.org/10.1088/1757-899X/330/1/012107.

[10] $\mathrm{ACl}$ Committee 440. 2000. Guide for the Design and Construction of Externally Bonded FRP Systems for Strengthening Concrete Structures. Research Report No. R02. American Concrete Institute, Farmington Hills, Mich, USA, January. 79

[11] Hyer M. W. 1998. Stress Analysis of Fiber-Reinforced Composite Materials, McGraw-Hill company, Singapore.

[12] Norris, T., Saadatmanesh, H. and Ehsani, M. R. 1997. Shear and Flexural Strengthening of R/C Beams with Carbon Fiber Sheets. Journal of Structural Engineering, 123(7): 903-911. DOl:https://doi.org/10.1061/(ASCE)07339445(1997)123:7(9 03).

[13] Campione, G., La Mendola, L. and Papia, M. 2005. Flexural Behaviour of Concrete Corbels Containing Steel Fibers or Wrapped with FRP Sheets. Materials and Structures. 38(6): 617-625. DOI: https://doi.org/10.1007/BF02481593.

[14] Ahmad, S., Shah, A., Nawaz, A. and Salimullah, K. 2010. Shear Strengthening of Corbels with Carbon Fibre Reinforced Polymers (CFRP). Materiales de Construcción. 60(299): 79-97. DOI: https://doi.org/10.3989/mc.2010.50009.

[15] Syroka, E., Bobiński, J. and Tejchman, J., 2011. FE Analysis of Reinforced Concrete Corbels with Enhanced Continuum Models. Finite Elements in Analysis and Design. 47(9): 10661078. DOI: https://doi.org/10.1016/j.finel.2011.03.022.

[16] Rezaei, M., Osman, S. A. and Shanmugam, N. E. 2013. Primary and Secondary Reinforcements in Reinforced Concrete Corbels. Journal of Civil Engineering and Management.19(6): 836-845 DOI: https://doi.org/10.3846/13923730.2013.801896.

[17] Assih, J., Ivanova, I., Dontchev, D. and Li, A. 2015. Concrete Damaged Analysis in Strengthened Corbel By External
Bonded Carbon Fibre Fabrics. Applied Adhesion Science. 3(1): 1-13. DOI: https://doi.org/10.1 186/s40563-015-0045-1.

[18] Shadhan, K.K. and Kadhim, M. M. M. 2015. Use of CFRP Laminates for Strengthening of Reinforced Concrete Corbels. Int. J. Civ. Eng. Technol. 6(11): 11-20.

[19] Neupane, R. C., Eddy, L. and Nagai, K. 2017. Investigation on Strengthening Approaches Adopted for Poorly Detailed RC Corbels. Fibers. 5(2): 16. DOI: https://doi.org/10.3390/fib5020016.

[20] Khosravikia, F., Kim, H. S., Yi, Y., Wilson, H., Yousefpour, H. Hrynyk, T. and Bayrak, O. 2018. Experimental and Numerical Assessment of Corbels Designed Based on Strutand-Tie Provisions. Journal of Structural Engineering. 144(9): 04018138.

DOI: https://doi.org/10.1061/(ASCE)ST.1943-541X.0002137.

[21] Campione, G. and Cannella, F. 2020. Analytical Model for Flexural Response of Reinforced Concrete Corbels Externally Strengthened with Fiber-Reinforced Polymer. ACl Structural Journal. 117(4): 91-102.

DOI: https://doi.org/10.14359/51721374.

[22] Abu-Obaida, A., El-Maaddawy, T. and El-Ariss, B. 2020. Numerical Simulation of Double-sided Concrete Corbels Internally-reinforced with GFRP Bars. Composites Part C: Open Access. 2: 100040.

DOI: https://doi.org/10.1016/j.jcomc.2020.100040.

[23] Ivanova, I., Assih, J. and Dontchev, D. 2020. Influence of Anchorage Length of Composite Fabrics and Bonded Surface on the Strengthened Short Reinforced Concrete Corbel by Bonding CFRF. European Journal of Environmental and Civil Engineering. 24(12): 1993-2009. DOI: https://doi.org/10.1080/19648189.2018.1498395.

[24] Ivanova, I., Assih, J., Li, A., Dontchev, D. and Delmas, Y. 2015. Experimental Investigation into Strengthened Short Reinforced Concrete Corbels by Bonding Carbon Fiber Fabrics. Journal of Adhesion Science and Technology. 29(20): 2176-2189.

DOI: https://doi.org/10.1080/01694243.2015.1060060

[25] Hognestad, E. 1951. Study of Combined Bending and Axial Load in Reinforced Concrete Members. University of Illinois at Urbana Champaign, College of Engineering. Engineering Experiment Station. DOI: http://hdl.handle.net/2142/4360.

[26] Loo, Y. C. and Yao, B. Z. 1995. Static and Repeated Load Tests on Precast Concrete Beam-to-column Connections. Pci Journal. 40(2):106-115. DOI: https://doi.org/10.15554/pcij.0301 1995.106.115. 